CERIF: S181

\author{
Dr. Miloš Milošević*
}

\author{
Dr. Mihajlo Babin ${ }^{* *}$
}

\title{
POTENTIALS AND STRUCTURE OF FISCAL DEVALUATION IN SERBIA
}

Fiscal devaluation is a set of synhronized policy measures with the aim to stimulate economic growth and improve economy competitiveness by simultaneous decrease of gross labor costs and increase of tax burden on consumption. The precondition for successful fiscal devaluation is to comply with principle of fiscal neutrality. Fiscal devaluation could enhance competitiveness of the economy and contribute to improved trade balance. Implementation of fiscal devaluation might be beneficial to both, countries which belong to a currency union and countries with a high level of public debt denominated in foreign currency. Comparative analysis provided potential short and long term effects of fiscal devaluations and enabled assessment of structure of fiscal devaluation in Serbia. This article provides a framework for forthcoming debates on applicability of fiscal devaluation in Serbia and includes the potential structure of fiscal devaluation.

Key words: $\quad$ Fiscal devaluation. - Serbia. - Competitiveness. - Trade balance. Employment.

\section{INTRODUCTION}

The time of economic crisis is especially adequate for fiscal policy adjustments due to the necessity to stabilize economy in short term and enable sustainable economic development in mid and long term. The prebg.ac.rs.

* Assistant Professor, University of Belgrade Faculty of Law, milosevic@ius.

** Assistant Professor, Singidunum University, Faculty of Economics, Finance and Administration,mbabin@fefa.edu.rs. 
condition for effective implementation of active fiscal policy measures is acceptance of the fiscal neutrality principle. This principle signifies that the aggregate effect of fiscal policy changes must be revenue neutral and consequently not jeopardize maintenance of macroeconomic stability. Complying with fiscal neutrality principle enables creation of new solutions and might deliver Pareto improvement.

\section{PRE-CONDITIONS FOR FISCAL DEVALUATION}

Fiscal devaluation is a set of synhronized policy measures with the aim to stimulate economic growth and improve competitiveness of the economy by simultaneous decrease of gross labor costs and increase of tax burden on consumption. Therefore, fiscal devaluation consists of income tax burden decrease and increase of VAT (value added tax) or other types of consumption taxes. Fiscal devaluation can generate positive macroeconomic effects which are equivalent to the effects of exchange rate devaluation. ${ }^{1}$ Namely, implementation of fiscal devaluation enables downsizing of productions costs, which in turn improves price competitiveness of domestic products at international markets.

The rationale for active fiscal policy relies within the long-lasting and prevailing negative macroeconomic effects of existing fiscal framework in a certain country. These effects can be summarized as follows:

a. negative or low rates of economic growth;

b. low share of investment in GDP (gross domestic product);

c. high and persisting rate of unemployment;

d. high ratio of gray economy to GDP and

e. long-lasting trade accounts deficit.

Although some of these effects might be decreased or neutralized in absence of any fiscal policy adjustments in mid and long-term it is very important to highlight exorbitant unnecessary losses and negative impact of these effects on economic development. Fiscal policy reforms do not guarantee anticipated results and outcomes, while different adverse effects may arise, corrupting or completely neutralizing implemented measures.

Fiscal devaluation contributes to economic growth and increased exports through two streams which strenghtens price competitiveness:

a. smaller gross labor costs allow price decrease of final products and

1 E. Farhi, G. Gopinath, O. Itskhoki, Fiscal devaluations, NBER Working Paper, No. 17662, National Bureau of Economic Research 2011, 5. 
b. VAT is levied on importers and is reimbursed to exporters - increased VAT rate has no negative effects on exports whatsoever.

Smaller gross costs per employee enable more opportunities for companies to invest in new technologies and equipment. These potential effects are especially relevant in capital intensive sectors. Also, in labor intensive sectors fiscal devaluation might open the possibility for hiring of new employees without putting additional pressure on the overall company costs. Fiscal devaluation could also be the remedy for high unemployment and persistent existence of unregistered workers and consequently support government efforts to decrease share of gray economy.

Countries can become more competitive if they manage to cut relative wages or if they become more productive. Productivity gains can be expected in mid and long term as results of changes in regulation and behaviour. In short term, competitiveness can be improved by depreciation of the currency in countries with flexible exchange rate regimes and by explicitly cutting relative nominal wages and prices in countries within a common currency area. ${ }^{2}$

Fiscal devaluation might be important for competitiveness convergence in countries which belong to monetary union, such as the EMU (European Monetary Union), with the aim to support structural reforms. ${ }^{3}$ The same currency hinders economic growth of periphery countries of the euro zone (Greece, Italy, Portugal and Spain), which suffer extreme difficulties in restoring their competitiveness and fostering sustainable economic growth. Quantitative simulations show that revenue-neutral shifts (the fiscal neutrality principle) from the employers' social contribution toward the VAT in euro zone countries could indeed improve the trade balance, with quite sizable short-run effects. ${ }^{4}$ This analysis emphasizes that positive effects of fiscal devaluation disappear in the long run and that such shifts rest largely on their potential to accelerate adjustment to deeper underlying problems. Fiscal devaluation is not "a substitute for deeper structural reforms of labor, product and financial markets" and can be perceived as "part of a broader package of reforms to regain external competitiveness by enhancing the flexibility of prices and wages as well the quality and variety of goods produced". 5 The examples of implement-

2 O. Blanchard, F. Jaumotte, P. Loungani, "Labor market policies and IMF advice in advanced economies during the Great Recession", IZA Journal of Labor Policy 3(1) 2014, 12.

3 P. Engler et al., Fiscal Devaluation in a Monetary Union, WP/14/201, International Monetary Fund 2014, 29-30.

4 R. de Mooij, M. Keen, "Fiscal Devaluation" and Fiscal Consolidation: The VAT in Troubled Times, WP/12/85, International Monetary Fund 2012, 36.

5 I. Koske, Fiscal Devaluation-Can it Help to Boost Competitiveness?, OECD Economics Department Working Paper, No. 1089, OECD Publishing 2013, 6. 
ed fiscal devaluation provide a framework for assessment applicability and potential effects of fiscal devaluation in Serbia.

\section{EXAMPLES OF FISCAL DEVALUATIONS}

Fiscal devaluation has been implemented in the following European countries in previous decades: Italy (three devaluations in the 1970s), Denmark (1988), Sweden (1993), Ireland (2002) and Germany (2007). Since the beginning of the World economic crisis it has been implemented in Spain and Finland (2010), the Netherlands (2012) and France (2014). ${ }^{6}$

Fiscal devaluation played an important role in the recommendations of the European Commission on tax shift in form of a fiscal devaluation in cases of Belgium, France, Germany, Italy, Latvia and Spain between the years 2011 and $2014 .^{7}$ However, it has only been applied in France and Spain. The expected effects in the short and long term are positive and might enhance restoration of competitiveness. Consequently, fiscal devaluation can be envisaged as a supporting policy for forthcoming deeper structural reforms. ${ }^{8}$

Simulations show that the unilateral implementation of fiscal devaluation might be the best option for a country to expand its GDP. The GDP effects become less favorable should three analyzed countries (France, Italy and Spain) coordinate fiscal devaluation. The implementation of fiscal devaluation in the entire euro zone would not be beneficial for individual member states. ${ }^{9}$ Potential positive impact of fiscal devaluation would be smaller or completely neutralized if other countries implement same shift of fiscal policy.

Additional simulations of fiscal devaluation implementation in cases of Spain and Portugal provide important evidence on its potential effects. The key potential effects are following: improvement of trade balance, growth of exports (which surpasses the growth of imports), increase of investment, increase of employment and positive impact on GDP growth. ${ }^{10}$ These potential effects prove high aptitude of fiscal devaluation to support macroeconomic stability improvement.

6 K. Bernoth, P. Burauel, P. Engler, "Fiscal devaluation: Economic stimulus for crisis countries in the euro area", DIW Economic Bulletin 4(10) 2014, 14.

7 L. Puglisi, Fiscal Devaluations in the Euro Area: What has been done since the crisis?, Taxation Paper No 47, Office for Official Publications of the European Communities, Luxembourg 2014, 11-12.

8 Ibid., 23.

9 European Commission, Study on the Impacts of Fiscal Devaluation, Taxation Paper No 36, Office for Official Publications of the European Communities, Luxembourg 2013, 153.

10 S. Gomes, P. Jacquinot, M. Pisani, Fiscal devaluation in the euro area: a model-based analysis, ECB Working Paper, No. 1725, European Central Bank 2014, 18. 


\section{APPLICABILITY AND STRUCTURE OF FISCAL DEVALUATION IN SERBIA}

Fiscal devaluation is especially relevant for countries that belong to a monetary union. Serbia does not belong to a monetary union and $\mathrm{Na}-$ tional Bank of Serbia independently governs the monetary policy. Currency depreciation is a possible policy option in Serbia and would lead to improvement of trade balance in the long run with negative effects in the short run. ${ }^{11}$ However, currency depreciation that would generate substantial impact on trade competitiveness is not a realistic solution due to the fact that any sharper depreciation of the currency would lead to a higher public debt to GDP ratio ${ }^{12}$ and would put additional pressure on budgetary stance. Consequently, implementation of fiscal devaluation as a substitute to currency depreciation seems to be an optimal policy endevour and might contribute to healing of underlying problems of Serbian economy and further contribute to the improvement of macroeconomic stability. $^{13}$

As previously stated, the basic scenario for fiscal devaluation implies a revenue neutral transfer of tax burden from employers' social security contributions to VAT. A reduction of production costs should result in a drop of the prices of domestic goods. This is how consumer standard is maintained on the existing level, without being negatively affected by a simultaneous increase of VAT. Of course, status quo is not possible if individual net salary is cut down, ${ }^{14}$ and/or consumption primarily relies on imported products where higher tax burden is not compensated by lower production costs. Domestic offer of adequate substitutes for more expensive imported products will cause a drop in the demand for the lat-

11 P. Petrović, M. Gligorić, "Exchange rate and trade balance: J-curve effect", $\mathrm{Pa}$ noeconomicus, 57(1) 2010, 38-39.

12 Serbian public debt is pre-dominantly denominated in foreign currency - US dollars and euros, http://www.javnidug.gov.rs/upload/Stanje i struktura/Stanje i struktura - SRB_LATINICA.pdf, last visited 15. September 2015.

13 M. Babin, M. Erić T. Papić, "Economic Crisis in Serbia: Hanging Over the Old Cliff", Revue europeenne de droit public= European review of public law = Eur. Zeitschrift des offtl. Rechts = Rivista europea di diritto pubblico, 25(1) 2013, 408-424.

14 And vice versa, an increase of net salary increases production costs and blocks up space for price reduction. "With a flexible exchange rate, the increased demand for exports and reduced demand for imports prompted by this tax shift would cause an appreciation of the nominal exchange rate that undoes its competitiveness impact. And even if the exchange rate is fixed, a fiscal devaluation will have no real effect if - or when domestic wages adjust, as one would expect them to do: as workers find their real wage reduced by the increased VAT rate, they (or their unions) will aim to increase their nominal wages, moving the real producer wage back to the pre-reform equilibrium.", R. de Mooij, M. Keen, 7. 
ter on the domestic market, while an increased demand for domestic goods will stimulate economic growth and employment. Also, lower production costs positively affect the competitiveness of domestic suppliers compared to the foreign ones, thus enabling better placement of domestic products on foreign markets and improving the country's foreign trade balance. This is, of course, provided that the countries that import domestic products are not undergoing similar reforms at the same time.

Summa summarum, direct results of the described strategy are embodied in the reduction of foreign trade deficit and unemployment without any negative implications to the existing welfare of the population. Lower domestic production costs stimulate economic growth and foreign investment. Stricter taxation of consumption financed by funds earned in the area of gray economy, i.e. other untaxed income (such as transfers from abroad) will contribute to fiscal consolidation. ${ }^{15}$

It can be concluded that Serbia is an almost ideal candidate for fiscal devaluation, which is primarily implied by the following parameters: high unemployment rate, ${ }^{16}$ significant share of gray economy in GDP, ${ }^{17}$

15 In relation to this, note that in countries with high degree of corruption and low tax morale it is desirable to primarily rely on consumption taxation, instead of direct taxes, G. Ilić-Popov, D. Popović "Poreska struktura i korupcija", Anali Pravnog fakulteta u Beogradu 1/2014, 12. Therefore, the highest corruption perceptions index among the member states of the Organization for Economic Cooperation and Development (OECD) in 2014 is found in Mexico, Greece, Italy, Turkey and Slovakia, Transparency International, Corruption Perceptions Index 2014, https://www.transparency.org/cpi2014/results, last visited 5. September 2015. In 2009, all these countries except Italy saw higher share of consumption tax in total tax revenue in relation to the average numbers among the OECD member states. Alongside Chile, Mexico and Turkey had the highest share of consumption tax in total tax revenue among the OECD countries, OECD, Consumption Tax Trends 2012: VAT/GST and Excise Rates, Trends and Administration Issues, OECD Publishing, Paris 2012, 29. In the EU (the European Union) the highest share of indirect taxes in total tax revenue in 2012 was seen in Bulgaria, Croatia and Romania, Eurostat, Taxation trends in the European Union, Data for the EU Member States, Iceland and Norway, Publications Office of the European Union, Luxembourg 2014, 178. Alongside Greece and Italy, these three countries fall into the category of the EU members with the highest corruption perceptions index.

16 According to a Labor Force Survey, in the second quarter of 2014, unemployment rate, which represents the share of the unemployed in the total number of active residents (employed and unemployed), amounted to 20,3\%, Republički zavod za statistiku, http://webrzs.stat.gov.rs/WebSite/Public/PublicationView.aspx? $p$ Key $=41 \& p L e v e ~ l=1$ $\&$ pubType $=2 \&$ pubKey $=2495$, last visited 6 . September 2015. To compare with, at the end of January 2015, the unemployment rate in EU28 amounted to 9.8\%, Ministarstvo finansija Republike Srbije, Bilten javnih finansija za januar 2015. godine, Ministarstvo finansija Republike Srbije, Beograd 2015, 11.

17 Using the MIMIC method, the volume of gray economy in Serbia was estimated to be at $30.1 \%$ of GDP, Fond za razvoj ekonomske nauke, Siva ekonomija u Srbiji: Novi nalazi i preporuke za reforme, rezime studije, http://www.policycafe.rs/documents/ loop/siva-ekonomija-u-srbiji-rezime.pdf, last visited 6. September 2015. 
pronounced foreign trade ${ }^{18}$ and - constantly present for years - budget deficit.

However, it should be taken into account that such reform is quite risky, because it may lead to the deterioration of the population's existing standard of living, while the expected positive results attributed to it may fail to appear. This scenario would happen if the realized savings in labor costs were to become a profit for businesses. ${ }^{19}$ That would block up space for price correction and the competitiveness of the domestic economy would remain at the existing level. The expected export, employment and investment increase would not appear, although higher VAT would improve the state of the treasury and lead to a fairer distribution of tax burden in the society by higher coverage of the income that escapes taxation with personal income tax. However, at the same time, that would lead to increased costs of living which is not appropriate, having in mind the current level of average net salary in Serbia, which amounts to RSD $45,601.00^{20}$ or $€ 380.54$.

In order to prevent the described risk, it is our opinion that fiscal devaluation should be implemented in two stages. The first one would see the increase of VAT, accompanied by the implementation of certain compensation measures that serve to maintain the population's standard. The second stage should lead to the reduction of production costs, as well as improved competitiveness of domestic manufacturers.

Considering the authors objective to use this paper to point to the idea and provide basic guidelines for the implementation of fiscal devaluation, the presentation of potential compensation measures is limited to employed persons. Whether the implementation of the suggested or alternative measures is justified and adequate in other cases, remains to be discussed separately, independently from this paper.

The reduction of employees' social security contributions (especially for pension and disability insurance) seems to be an adequate response to stricter taxation with VAT. An equal effect would be achieved

18 In 2014, Serbia exported USD 14845.1 million, and imported USD 20609.1 million worth of goods, so the coverage of import by export in the given period totalled $72 \%$, with a USD 5764.0 million deficit, Republički zavod za statistiku, http://webrzs.stat. gov.rs $/$ WebSite/public/PublicationView.aspx? $p$ Key $=41 \& p$ Level $=1 \&$ pubType $=2 \& p u b$ Key $=3059$, last visited 6. September 2015.

19 Precisely referring to this argument, fiscal devaluation saw great resistance and was not implemented in Portugal, L. Puglisi, 21.

20 Average net salary in July 2015, Cekos In, Prosečne neto zarade po zaposlenom prema statističkim teritorijalnim jedinicama, http://www.cekos.rs/prose\%C4\%8Dne-netozarade-plate-jul-2015-godine, last visited 7. September 2015. In May 2015, the average pension paid in Serbia amounted to RSD 22,738.00 ( $€$ 190.46), Ministarstvo finansija Republike Srbije, Bilten javnih finansija za maj 2015. godine, Ministarstvo finansija Republike Srbije, Beograd 2015, 9. 
by reducing tax burden on salaries. ${ }^{21}$ For these measures to be effective, it is essential to stipulate gross salary when entering a labor relationship, whereby the reduction of the given duties would automatically lead to increased net salary, thus compensating for higher consumption costs. ${ }^{22}$

The second component of the first stage of fiscal devaluation would imply stricter consumption taxation by means of general turnover tax. However, other tax forms are just as adequate to compensate for lower employers' contributions. What matters is that those taxes do not increase production costs, which would neutralize the savings made by businesses. Speaking of this, we particularly refer to excise taxes. ${ }^{23}$ However, excise tax revenues might be highly volatile if the tax burden increases. Therefore, a significant increase of excise taxes might not generate enough revenues to enable fiscally neutral reform.

With the standard VAT rate of $20 \%{ }^{24}$, Serbia falls into the category of countries with moderate tax burden, compared to a majority of the EU member states. Germany, Cyprus, Malta and Luxembourg have a lower standard VAT rate. Bulgaria, Estonia, France, Austria, Slovakia and the UK are in the same category as Serbia. The remaining 18 member states have a higher standard VAT rate, led by Hungary $(27 \%)$. As regards the reduced $10 \%$ rate $^{25}$, it is more complicated to make a comparison, considering that 15 member states implement more than one. We can claim with certainty that 12 member states have unique or several reduced rates under $10 \%$, five member states have the reduced rate of $10 \%$, mostly combined with lower rate(s), Latvia has a higher reduced rate $(12 \%)$

21 Literature also contains mentioning of the reduction of personal income tax, L. Puglisi, 12. However, the schedular component of the personal income taxation system in Serbia is characterized by different effective tax rates whose uniform decrease implies an overall revision of the existing regulations. Also, the revenues generated by personal income tax (which include the revenues from payroll tax) is divided between central authorities and smaller political-territorial units based on a formula established by law, Article 35 (1) (1) of the Law on Financing of Local Self-government, Official Gazette of the Republic of Serbia, No. 62/06, 47/11 and 93/12. It is questionable to which extent local self-government units would agree to this approach even under the condition that there is a complex compensation procedure for outstanding revenues from the funds provided through increased VAT that belongs to the state budget, Article 2 of the Law on Value Added Tax, Official Gazette of the Republic of Serbia, No. 84/04, 86/04, 61/05, 61/07, $93 / 12,108 / 13,68 / 14$ and 142/14. On the other hand, lack of contributions, for example for pension and disability insurance, would be simply compensated through routine practice of transfer to the Serbian Pension and Disability Insurance Fund.

22 In the conditions of stipulated net salary, employer could again be the one to benefit the most from reduced employee's contributions - by gaining profits at the expense of reduced labor costs on the equal level of net salary.

23 In this context, literature also suggests to increase residential property taxation, R. de Mooij, M. Keen, 23.

24 Article 23 (1) of the Law on Value Added Tax.

25 Article 23 (2) of the Law on Value Added Tax. 
while Denmark uniformly implements a standard rate of $25 \%$. The remaining nine member states combine reduced rates lower or equal to $10 \%$ with those over $10 \% .{ }^{26}$ A comparative review shows that there is room to increase VAT rates in Serbia to the level of those implemented in the EU.

In relation to the question by how much should VAT be increased in order to compensate for deficit of employees' contributions, without jeopardizing the existing personal standard, we present some logical observations. The basis for the calculation of contributions is gross salary. On the other hand, the basis for the calculation of VAT is net consumption which cannot exceed net salary (which funds gross consumption), reduced by the accompanying VAT. In other words, the basis for the calculation of VAT is much lower than the one for the calculation of contributions, which proves that a reduction of contributions by $1 \%$ enables a proportionally higher growth of VAT while maintaining the same level of personal welfare. ${ }^{27}$ This works for both VAT rates. However, the space for the growth of the reduced rate is somewhat smaller considering the higher share of net consumption in gross salary. Therefore, the larger the range between net consumption and gross salary, the bigger the space for VAT increase and vice versa. ${ }^{28}$

Since the implementation of a reduced rate serves to moderate the regressive effect of VAT, it is disputable how acceptable its growth is, above all for social reasons. However, since the ones to benefit the most from such a relief are those who do not need it, ${ }^{29}$ it is advisable to consider other protection measures for poorer population members, such as direct subsidies or higher existential minimum alongside progressive income taxation.

26 European Commission, VAT Rates Applied in the Member States of the European Union, Situation at $1^{\text {st }}$ September 2015, Taxud.c.1(2015) - EN.

27 Such transfer of tax burden would be particularly convenient for individuals who, by saving a part of net salary, avoid stricter consumption taxation, considering that the relation between consumption and savings in net salary is irrelevant for the amount of lower contributions.

28 On the EU level, an average of $65 \%$ of final consumption is taxed by standard VAT rate, F. Borselli, S. Chiri, E. Romagnano, "Patterns of Reduced VAT Rates in the European Union”, International VAT Monitor 1/2012, 16-17. Serbia has wider presence of taxation by means of reduced VAT rate. That is indicated by data on structure of personal consumption of households for 2014 in which expenses for food and non-alcoholic beverages on average covered a share of $38,4 \%$, while rent, water, electric energy, gas and other fuels occupied 16,1\%, Republički zavod za statistiku, Raspoloživa sredstva i lična potrošnja domaćinstava u Republici Srbiji, 2014, saopštenje br. 78 od 31.3.2015. godine, 1.

29 OECD, Korea Institute of Public Finance, The Distributional Effects of Consumption Taxes in OECD Countries, OECD Tax Policy Studies, No. 22, OECD Publishing, Paris 2014, 68-69. 
The second stage of the reforms would encompass the realization of the remaining element of the presented fiscal devaluation model - a reduction of employers' social security contributions, which would make room for lower costs of domestic production. A condition for this measure is a positive fiscal result of the previous stage of the reform, i.e. excess VAT revenue should improve public finances despite the deficit caused by employees' social security contributions. If the savings on labor costs would actually cause a drop in the domestic products' prices, fiscal devaluation would be a success. Otherwise, if they turn into a profit for businesses, unsuccessful fiscal devaluation would not jeopardize the existing welfare of the population.

In 2014, the total revenues from social security contributions in Serbia amounted to RSD 509,432.5 million, while RSD 409,564.2 million was collected through VAT. ${ }^{30}$ Even if we started from the fact that the given data refers only to the contributions paid on employment relationship (which is not the case), considering that employees' contributions have a share of around $52.6 \%$ in them, it is justified to assume that the condition for the second stage of fiscal devaluation would be fulfilled. Therewith, a $1 \%$ increase of reduced VAT rate would generate $10 \%$ higher revenues from the taxation of the supply of goods and services, or import of goods in accordance with Article 23 (2) of the Law on Value Added Tax, while in the same conditions the revenues from standard VAT rate would be boosted by $5 \%$. Therefore, proportional increase of both tax rates is a condition for a uniform growth of VAT revenues.

\section{CONCLUSION}

The goal of fiscal devaluation is to stimulate domestic production and make a positive impact on foreign trade balance and employment level by reducing labor costs (through lower employers' social security contributions) and introducing stricter consumption taxation. The constantly unfavorable economic situation in Serbia makes the potential benefits of such fiscal reform highly desirable. However, even though Serbia represents an almost ideal candidate for fiscal devaluation, there are certain risks it entails that need to be taken into consideration. If savings in labor costs were to become a profit for businesses, the expected effects would fail to appear. Such an outcome would deteriorate the population's already low standard of living, which is unacceptable. In order to prevent the described risk, we suggest to combine VAT increase with certain compensation measures whose goal is to maintain the existing welfare of the

30 Ministarstvo finansija Republike Srbije, Bilten javnih finansija za decembar 2014. godine, Ministarstvo finansija Republike Srbije, Beograd 2014, 46. 
population. Only then the remaining element of the advocated fiscal devaluation model - the reduction of employers' social security contributions - should be realized in order to reduce the domestic production costs and strengthen the competitiveness of the domestic suppliers in relation to foreign competition.

The actual effect of fiscal devaluation will depend on the scale of the reform, as well as on numerous specificities of the country that considers its implementation. Previously conducted research mostly provides evidence about positive, although modest effects of fiscal devaluation. Therefore, fiscal devaluation cannot be considered a cure that would bring economic recovery to Serbia, but it could be an addition to thorough system changes in that direction. 